\title{
DETERMINANTS OF PUBLIC-PRIVATE PARTNERSHIPS IN INFRASTRUCTURE IN ASIA: IMPLICATIONS FOR CAPITAL MARKET DEVELOPMENT
}

Suk Hyun, Donghyun Park, and Shu Tian

NO. 552

August 2018
ADB ECONOMICS WORKING PAPER SERIES 


\section{Determinants of Public-Private Partnerships in Infrastructure in Asia: Implications for Capital Market Development}

Suk Hyun, Donghyun Park, and Shu Tian

No.552 | August 2018
Suk Hyun (bigsuk@gmail.com) is a Research Fellow in the Korea Capital Market Institute. Donghyun Park (dpark@adb.org) is a Principal Economist and Shu Tian (stian@adb.org) is an Economist in the Economic Research and Regional Cooperation Department of the Asian Development Bank.

This paper has been prepared as background material for the Asian Development Outlook 2017 Update theme chapter on Sustaining Development through PublicPrivate Partnership. The authors would like to thank Cynthia Castillejos-Petalcorin and Mai Lin Villaruel for their excellent research assistance. 
(C) 2018 Asian Development Bank

6 ADB Avenue, Mandaluyong City, 1550 Metro Manila, Philippines

Tel +632632 4444; Fax +6326362444

www.adb.org

Some rights reserved. Published in 2018.

ISSN 2313-6537 (print), 2313-6545 (electronic)

Publication Stock No. WPS189466-2

DOI: http://dx.doi.org/10.22617/WPS189466-2

The views expressed in this publication are those of the authors and do not necessarily reflect the views and policies of the Asian Development Bank (ADB) or its Board of Governors or the governments they represent.

ADB does not guarantee the accuracy of the data included in this publication and accepts no responsibility for any consequence of their use. The mention of specific companies or products of manufacturers does not imply that they are endorsed or recommended by ADB in preference to others of a similar nature that are not mentioned.

By making any designation of or reference to a particular territory or geographic area, or by using the term "country" in this document, $A D B$ does not intend to make any judgments as to the legal or other status of any territory or area.

This work is available under the Creative Commons Attribution 3.0 IGO license (CC BY 3.0 IGO)

https://creativecommons.org/licenses/by/3.o/igo/. By using the content of this publication, you agree to be bound by the terms of this license. For attribution, translations, adaptations, and permissions, please read the provisions and terms of use at https://www.adb.org/terms-use\#openaccess.

This CC license does not apply to non-ADB copyright materials in this publication. If the material is attributed to another source, please contact the copyright owner or publisher of that source for permission to reproduce it. $\mathrm{ADB}$ cannot be held liable for any claims that arise as a result of your use of the material.

Please contact pubsmarketing@adb.org if you have questions or comments with respect to content, or if you wish to obtain copyright permission for your intended use that does not fall within these terms, or for permission to use the ADB logo.

Notes:

In this publication, "\$” refers to United States dollars.

ADB recognizes "Hong Kong" as Hong Kong, China and "Korea" as the Republic of Korea.

Corrigenda to ADB publications may be found at http://www.adb.org/publications/corrigenda. 


\section{CONTENTS}

TABLES AND FIGURES

ABSTRACT

$\begin{array}{ll}\text { I. INTRODUCTION } & 1\end{array}$

II. OVERVIEW OF PUBLIC-PRIVATE PARTNERSHIPIN INFRASTRUCTURE FINANCING 2

III. LITERATURE REVIEW 4

IV. $\quad$ DATA AND EMPIRICAL APPROACH

A. Data 5

B. Empirical Analysis 10

V. CONCLUSION

$\begin{array}{ll}\text { APPENDIX } & 19\end{array}$

$\begin{array}{ll}\text { REFERENCES } & 21\end{array}$ 


\section{TABLES AND FIGURES}

\section{TABLES}

$1 \quad$ Determinants of Private Participation in Infrastructure Investment 6

2 Descriptive Statistics 7

3 Correlation Matrix 8

4 Determinants of Public-Private Partnership: Panel Regression with Fixed Effect 13

5 Determinants of Public-Private Partnership: Difference Generalized Method of Moments Regression $\quad 14$

6 Determinants of Public-Private Partnership: Dynamic Panel Fixed Effect Regression 15

$7 \quad$ Determinants of Public-Private Partnership: System Generalized Method

of Moments Regression 16

\section{FIGURES}

1 Public-Private Partnership Infrastructure Investment Across Years in 12 Selected Emerging Economies

2 Annual Average of Public-Private Partnership Investment Across Countries 


\begin{abstract}
In this study, we attempt to understand the role of greater access to finance, i.e., stocks, bonds, and bank loans, in public-private partnership (PPP) investment in developing countries. Most developing countries still depend heavily on fiscal financing for infrastructure projects. Our empirical results reconfirm the fact that banks remain the major source of finance for infrastructure projects. The domestic bond market should be further developed to have depth and liquidity enough to provide longterm funding for private sector investors. Interestingly, we find a negative impact of bond market development on PPP investment. A possible interpretation is that financing through government bonds, which dominates bond markets in developing countries, discourages private sector participation by reducing financing access to the corporate bond market. Our evidence underlines the importance of a well-functioning corporate bond market in developing countries, which can offer long-term financing to private sector participation in infrastructure investments.
\end{abstract}

Keywords: bond market development, government bond, public-private partnership

JEL codes: E20, G10, H00 


\section{INTRODUCTION}

Infrastructure brings more inclusive and higher economic growth, and governments recognize that their citizens and businesses will continue to demand more infrastructure access and services because they expect that infrastructure improves productivity of economy and quality of life. However, governments are also struggling to secure funds for infrastructure development due to increasing fiscal burden. Both governments and private sectors have too limited resources to build infrastructures and to cover all the risks inherent in infrastructure projects. The role of the public sector has traditionally been played to provide specific services such as defense, security, education, and health and basic infrastructure such as roads or airports. On the other hand, the private sector is reluctant to provide infrastructures because of lack of profitability, a long duration in construction and operation, as well as capital intensity, and a complex valuation process (Grimsey and Lewis 2002). Also, natural monopolies exist in infrastructure industries with high initial costs and a large-scale investment and significant entry barriers. Building competing infrastructures would be inefficient and, therefore, require the public sector's provision of infrastructure and public intervention. ${ }^{1}$

Although the public sector is still responsible for providing infrastructure, the financing role has changed recently from government coffers to the private sector. In fact, the role of the private sector in financing infrastructure projects has been increasingly important over time. However, it is challenging to stimulate private participation in the provision of infrastructure, and even more so for low-income and developing countries. The essential problem of developing countries in attracting private investors in the infrastructure sector results from their poor sovereign creditworthiness, underdevelopment of financial markets, and high economic risk inherent in infrastructure projects (Sheppard, von Klaudy, and Kumar 2006; Saidi 2006; and Jerome 2008). To overcome these drawbacks, partnerships between the public and private sectors have been viewed as one of the financial mechanisms that would allow gathering and channeling the needed amount of resources for sustainable growth and poverty reduction in developing countries (World Bank 2006).

What has been generally known from existing literatures to identify major determinants for public-private partnership (PPP) investments is that PPP investments tend to be more common in countries whose governments suffer from heavy debt burdens, where aggregate demand is sizable enough to allow for cost recovery and profitability. Macroeconomic stability, especially low inflation, is critical for PPPs because of long duration in construction and operation of infrastructure projects. From institutional aspects, many PPP projects are found in countries with less corruption and effective rule of law and with PPP experiences. This research extends the extant literature and attempts to understand whether more financing accessibility to private sectors such as stocks, bonds, and bank loans will encourage PPP investments using the World Bank Private Participation in Infrastructure (WB PPI) database for developing countries after controlling the known determinants of PPP investments. This study aims to establish how the availability of financial markets influences the efficient implementation of PPP projects.

1 Lack of infrastructure implies market failure because of externalities, the existence of public goods, and asymmetric information problems (Sawada 2015). 
The paper is organized as follows. Section II overviews PPP in infrastructure projects and the role of capital market in infrastructure financing and section III reviews the existing literatures that identify major determinants of PPPs in infrastructure. Section IV describes the datasets used in this paper and presents our empirical models and our results on the determinants of PPP arrangements in selected lowincome developing economies. Lastly, section $\vee$ identifies the limitations to attract private capital and provide implications for harnessing the private sector investment based on empirical results.

\section{OVERVIEW OF PUBLIC-PRIVATE PARTNERSHIP IN INFRASTRUCTURE FINANCING}

In general, the financial structure of PPP should minimize the financing cost, be bankable, and fulfill the contractual obligations by transferring the responsibility and the risk to the private party to allocate funds to large-scale infrastructure projects. ${ }^{2}$ PPPs can be financed mainly with three financing mechanisms: public sector finance, corporate finance, and project finance. Public sector finance is that the state or government finances part or all the capital investment needed for the project, while the private sector provides know-how. With corporate finance, the private sector finances the project with its own credibility. This mechanism is typically used in projects where the private operator is large enough to finance the project with its own balance sheet. Project finance is generally known as limited resource financing through a specific company created for the project, usually called as special purpose vehicle (SPV).

The SPV functions as bankruptcy-remote subsidiary for parent company, and its role is limited to the acquisition and financing of specific assets. The SPV can raise capital without carrying the debt or other liabilities of the parent company, although the subsidiary is often operated by the same entities and provides the construction and operation needed to meet the requirements of the PPP contract operations. Private partners in PPP contracts require an SPV as part of the arrangement, especially for large infrastructure projects. The SPV assumes the responsibilities and makes arrangements for funding, usually in the form of project finance in which the main source of payment is based on the future cash flows generated from the project.

PPPs are financed by project finance through an SPV and have two funding sources: equity and debt. Equity financing might be optimal for the government shareholding structure. The government shareholding can lower the cost of capital and attract more private participation, and can consequently increase the quality of PPP projects. In addition, in the case of emerging markets with underdeveloped financial markets, the participation of the government can help to secure private investment by correcting market failure (Moszoro 2014) since the cost of capital for a private party is on average 100-300 basis points higher than for the public sector (Moszoro and Gąsiorowski 2008). On the other hand, PPPs are highly leveraged, with debt financing approximately $70 \%-90 \%$ of the project total cost. Debt providers care about the downside risk and the measures to mitigate the risk. Although the contractual arrangement is made between the public and the private sector, the lenders set the parameters to mitigate the risk and assess if the project can be financed. In the end, this risk evaluation is reflected in the risk premium, which is included in the cost of debt (Singh and Kalidindi 2009).

2 Contrary to the original intention to reduce government burden, some PPP cases in emerging economies did not relieve fiscal burdens because they were eventually rescued by government budgets from the perspective of social necessity when infrastructure projects failed. In some cases, such government support without the appropriate risk-sharing mechanism might cause moral hazard problems with the private sectors involved in the project. 
Many developing countries undertook structural reforms of their infrastructure sectors from the late 1980s to the early 1990s with the purpose of facilitating competition through liberalization and privatization; improving the regulatory environments; and attracting private and foreign actors in infrastructure ownership, management, operation, and service provision. Despite these reforms, developing economies should further harness private sector investment in infrastructure with coordinated reforms for the finance sector. Financing accessibility, especially bond financing, has become an alternative avenue for infrastructure financing because of rising fiscal burden and falling bank lending under regulatory change like Basel III. ${ }^{3}$ To compare bank financing with bond financing in project financing in PPP, bank loan is made via the direct relationship between lenders and borrowers by financial intermediation, and can be characterized as a negotiable financing tool such as flexible disbursement and rescheduling of repayment. Conditions and terms of loans could be negotiated between related parties through the clause amendment and waivers of loan agreement. Banks investigate the creditability of prospective projects, and screen safe borrowers from less safe ones. After the loan is made, banks often monitor the borrower's business to prevent the moral hazard problem. Activities such as information gathering and monitoring are conducted on a bilateral basis between borrowers and lenders.

On the other hand, bond issuance could be described as direct financing via financial markets from the broad base of investors. To issue bonds, a firm's financial conditions are scrutinized and rated, and the information gathered in the process is open to the public if necessary. Underwriting is critical for the dissemination of the debtor's information to the public as well as for the treatment of risks related to public offers. Bonds are standardized financial vehicles and, most importantly, transferable financing tools through the capital markets. Bond financing can cater to the financing needs of, especially, infrastructure projects by matching long gestation periods and by financing large amount of funds for construction, maintenance, and operation of infrastructures. Given this nature of infrastructure projects, bond financing is an alternative avenue since bank financing cannot match the long gestation period and large fund requirements in infrastructure industry, which are characterized as capital-intensive infrastructure projects in PPP because of single lending limits and large credit control and concentration risk in the case of bank financing.

Against these backdrops, attention is renewed to private sector participation in infrastructure financing to facilitate infrastructure developments in emerging countries. In our major results, private sector financing accessibility does not contribute to PPP investment, but interestingly we find that dominant government bond financing crowds out incentive to attract private investment. Low- and middle-income developing countries still depend heavily on the fiscal financing for infrastructure projects instead of utilizing private investment. This might result from underdeveloped corporate bond market in developing countries which cannot offer long-term financing for infrastructures.

3 The standard literature on project finance gives detailed explanations of advantages and disadvantages of the use of bond markets compared with bank loans. For example, see Hoffman (1998) and Yescombe (2002 and 2007). 


\section{LITERATURE REVIEW}

The public infrastructure provision through PPP is based on two different motives. Private sectors are seeking profits by providing services and infrastructure, while governments are concerned with both project's public nature and economic efficiency through private sector participation. To derive successful and effective partnerships, the public and private sectors share the same goal of quality, efficiency, and accountability in building infrastructure and delivering services. Then, what determines private sector participation in providing infrastructure and delivering public services? There are extensive literatures, which investigate the determinants of PPP investment in emerging economies.

In the case of Ghana during 1970-1992, Asante (2000) shows that public investment, lagged private investment, and the growth of real credit in the private sector are key determinants of private investment. However, the author finds that economic growth negatively influences private investment, and so does macroeconomic and political instability.

Zerfu (2001) finds that gross domestic product (GDP), its growth rate, and public investment in infrastructure significantly facilitate private investment in Ethiopia, while lack of macroeconomic stability tends to negatively affect investment.

Ouattara (2004) investigates the long-run determinants of private investment in Senegal from 1970 to 2000 and shows that public investment, GDP per capita, and foreign aid positively influence private investment. However, credit to the private sector and terms of trade surprisingly tend to hinder private investment in Senegal.

Hammami, Ruhashyankiko, and Yehoue (2006) present an empirical analysis of the crosscountry and cross-industry determinants of PPP investments over the period 1990-2003. They find that PPPs tend to be more common in countries where governments suffer from heavy debt burdens and where aggregate demand and market size are large. Their findings also suggest that macroeconomic stability is essential for PPPs. They emphasize the importance of institutional quality, where less corruption and effective rule of law are associated with more PPP projects.

Kinda (2008) examines the determinants of infrastructure private investment in 61 developing countries over the period 1970-2003, and finds a significant positive effect of economic growth, physical infrastructure, and level of development of the finance sector, especially credit granted to the private sector by the banking sector. He also finds that private investment is negatively associated with macroeconomic and political instability.

Ba, Gasmi, and Noumba Um (2010) investigate empirically the determinants of private investment in developing countries' power sectors, emphasizing the importance of economic growth and finance sector development, with dynamic panel model specifications for 37 developing countries from 1990 to 2007. They point out that a well-developed finance sector, especially well-established capital market with depth and liquidity, is found to be a key determinant of private investment in power sectors in developing countries.

However, Gupta and Gupta (2001) find that the development level of bond markets in most emerging economies is insignificant and, therefore, cannot offer financial and risk-mitigating 
instruments required for infrastructure projects. Emerging capital markets have not yet reached a level of development required to catalyze the development of private investment in infrastructure.

Sharma (2012) also analyzes the factors that determine PPP in infrastructure by using the WB PPI database for the period 1990-2008. The empirical results show that large size and relatively higherincome markets are positively associated with PPP investments; and macroeconomic stability, quality of regulation, and governance are positive factors in determining PPP in infrastructure.

Tewodaj (2013) empirically investigates the determinants of PPP in low- and middle-income countries (LMICs) and compares countries in sub-Saharan Africa with LMICS during 1995-2008. As for LMICs as a whole, countries with larger service sectors are more likely to receive PPP. Countries more open to trade, with larger populations, and democracies, are also more likely to receive PPP, as are countries with higher levels of fiscal freedom and availability of domestic credit, while aid and inflation are also significantly and negatively associated with PPP investment. However, as for countries in subSaharan Africa with larger service sectors, larger populations, and lower tax burdens are similarly significantly and positively correlated with PPP investments.

Kasri and Wibowo (2015) employ advanced panel estimations to develop a cross-country analysis of private finance determinants in 48 Islamic developing countries for the period 2000-2011. The evidence suggests that market conditions, institutional qualities, and country risks are the most crucial factors determining private investment in infrastructure financing in Muslim countries. Market condition such as population, income, and purchasing power and institutional quality are strongly associated with PPP. However, country risk is negatively related to PPP investments.

\section{DATA AND EMPIRICAL ANALYSIS}

\section{A. Data}

The main data source for PPP projects in developing countries is the World Bank database on PPI, which records projects based on publicly available sources. ${ }^{4}$ From the WB PPI dataset, we specify regression models with selected 12 LMICs, which have data available of financial and capital markets for 21 years, from 1995 to 2015. In line with Hammami, Ruhashyankiko, and Yehoue (2006) and Ba, Gasmi, and Noumba Um (2010), variables that may explain investment in PPP in developing countries have been collected and are listed in Table 1 and the Appendix. These variables are drawn from literatures such as aggregate demand or size of the economy, economic growth rate, finance sector variables, and fiscal condition, as well as institutional factors such as government stability. Different from previous studies, several volatility measures like growth volatility, inflation volatility, and exchange rate volatility are added to our estimation model since stability is expected to increase private investment for PPP projects.

The sources of data are the World Development Indicators database from the World Bank, and International Financial Statistics from the International Monetary Fund, Bank for International

4 We use the WB PPI database, which records contractual arrangements for PPP infrastructure projects in 139 LMICs as classified by the World Bank. The WB PPI database is the leading source of PPP trends in the developing world, covering projects in the energy, telecommunication, transport, and water and sewerage sectors. Projects include management or lease contracts, concessions, greenfield projects, and divestitures. While PPIs are arguably somewhat different from PPPs, the two concepts are often used interchangeably (Thomsen 2005). 
Settlement, and the International Country Risk Guide from the PRS Group. ${ }^{5}$ Table 2 reports descriptive statistics of all variables used in the estimation during the sample period 1995-2015 with 12 countries. ${ }^{6}$ Table 2 confirms that 12 countries have relatively developed stock markets and banking sectors compared with government bond markets and corporate bond markets. Table 3 presents correlation matrix for the variables used in the empirical analysis. Highly correlated explanatory variables are excluded in the dataset to minimize the collinearity problems.

Table 1: Determinants of Private Participation in Infrastructure Investment

\begin{tabular}{|c|c|c|c|}
\hline Research & Sample Coverage & Positive Drivers & Negative Drivers \\
\hline Asante 2000 & Ghana & $\begin{array}{l}\text { Public investment, } \\
\text { lagged private investment, and } \\
\text { growth of real credit to private sector }\end{array}$ & $\begin{array}{l}\text { Economic growth, } \\
\text { macroeconomic, and } \\
\text { political instability }\end{array}$ \\
\hline Zerfu 2001 & Ethiopia & $\begin{array}{l}\text { Gross domestic product (GDP), } \\
\text { GDP growth, and } \\
\text { public investment in infrastructure }\end{array}$ & Macroeconomic instability \\
\hline Ouattara 2004 & Senegal & $\begin{array}{l}\text { GDP per capita and } \\
\text { foreign aid }\end{array}$ & $\begin{array}{l}\text { Credit to the private sector, } \\
\text { and terms of trade }\end{array}$ \\
\hline $\begin{array}{l}\text { Hammami, } \\
\text { Ruhashyankiko, and } \\
\text { Yehoue } 2006\end{array}$ & $\begin{array}{l}\text { International } \\
\text { economies }\end{array}$ & $\begin{array}{l}\text { Heavy public debt burdens, } \\
\text { higher aggregate demand and market size, } \\
\text { macroeconomic stability, and } \\
\text { better institutional quality }\end{array}$ & \\
\hline Kinda 2008 & $\begin{array}{c}\text { Global developing } \\
\text { countries }\end{array}$ & $\begin{array}{l}\text { Economic growth, } \\
\text { physical infrastructure, and } \\
\text { bank credit to private sector }\end{array}$ & $\begin{array}{l}\text { Macroeconomic and } \\
\text { political instability }\end{array}$ \\
\hline $\begin{array}{l}\text { Ba, Gasmi, and } \\
\text { Noumba Um } 2010\end{array}$ & $\begin{array}{l}37 \text { developing } \\
\text { countries } \\
\text { (power sector) }\end{array}$ & $\begin{array}{l}\text { Public-private partnership experience } \\
\text { (lagged variable), } \\
\text { economic growth, and } \\
\text { financial development }\end{array}$ & Foreign exchange risk \\
\hline Tewodaj 2013 & $\begin{array}{l}\text { Low- and middle- } \\
\text { income countries }\end{array}$ & $\begin{array}{l}\text { Larger service sectors, } \\
\text { open trade, } \\
\text { large population, } \\
\text { democracies, } \\
\text { fiscal freedom, and } \\
\text { common law regime }\end{array}$ & Aid and inflation \\
\hline $\begin{array}{l}\text { Kasri and Wibowo } \\
2015\end{array}$ & $\begin{array}{l}48 \text { Muslim } \\
\text { developing } \\
\text { countries }\end{array}$ & $\begin{array}{l}\text { Population, } \\
\text { income, and } \\
\text { regulatory environment }\end{array}$ & Country risk \\
\hline
\end{tabular}

Source: Authors' summary.

5 The International Country Risk Guide is used extensively in econometric studies of investment for measures of institutional quality, economic, financial, and political risks, due to its large coverage of developing countries starting from the mid-1980s and the use of a consistent methodology in time and across countries.

6 We selected 12 countries from the WB PPI database, which has sufficient data for financial and capital markets such as bank loans, government bonds, corporate bonds, and stocks. The 12 countries are Argentina, Brazil, Chile, the People's Republic of China, Colombia, India, Indonesia, Malaysia, Mexico, South Africa, Thailand, and Turkey. 
Table 2: Descriptive Statistics

\begin{tabular}{llllll}
\hline Variables & N & Mean & Min & Max & Std \\
\hline Bond-to-GDP ratio & 212 & 0.40 & 0.01 & 1.21 & 0.28 \\
PPP-to-GDP ratio & 212 & 0.01 & 0.00 & 0.08 & 0.01 \\
PRI-to-GDP ratio & 212 & 0.01 & 0.00 & 0.06 & 0.01 \\
Credit-to-GDP ratio & 212 & 0.56 & 0.09 & 1.61 & 0.39 \\
Government bonds-to-GDP ratio & 212 & 0.24 & 0.00 & 0.89 & 0.18 \\
Corporate bonds-to-GDP ratio & 212 & 0.16 & 0.00 & 0.73 & 0.17 \\
Stock market capitalization-to-GDP ratio & 212 & 0.74 & 0.06 & 3.04 & 0.62 \\
Log of GDP per capita & 212 & 8.52 & 6.32 & 9.67 & 0.72 \\
GDP growth & 212 & 0.04 & -0.11 & 0.14 & 0.04 \\
Inflation rate & 212 & 0.08 & -0.01 & 0.88 & 0.13 \\
GDP growth volatility & 212 & 0.03 & 0.01 & 0.08 & 0.02 \\
Inflation volatility & 212 & 0.34 & 0.01 & 6.52 & 1.31 \\
Real effective exchange rate volatility & 212 & 0.02 & 0.00 & 0.15 & 0.02 \\
Exchange rate regime & 212 & 0.13 & 0.00 & 1.00 & 0.34 \\
Log of government stability index & 212 & 2.08 & 1.58 & 2.40 & 0.19 \\
\hline
\end{tabular}

$\mathrm{GDP}=$ gross domestic product, $\mathrm{PPP}=$ public-private partnership, $\mathrm{PRI}=$ PPP private investment.

Source: Authors' calculation. 


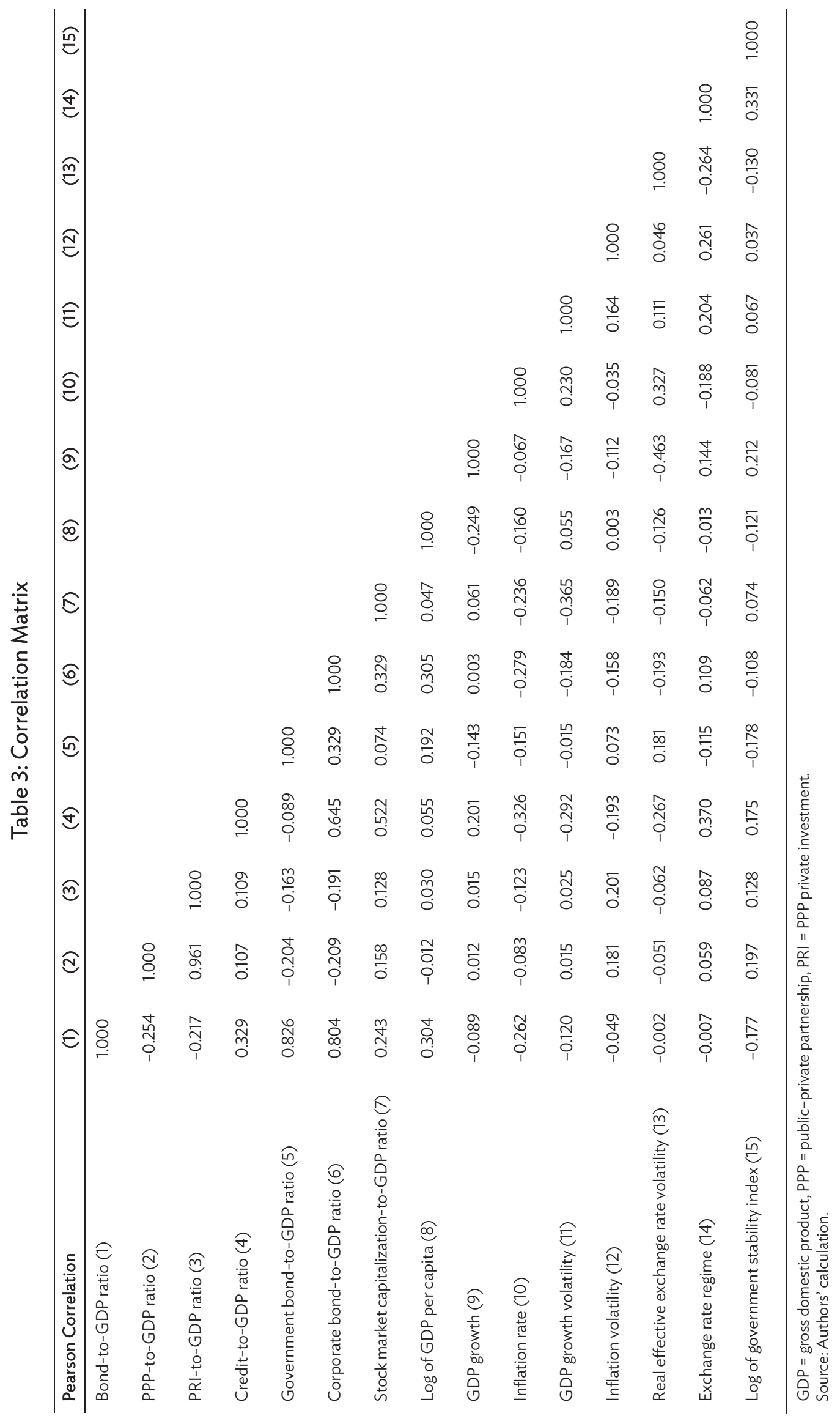


This study attempts to investigate whether more financial accessibility to private sectors such as stocks, bonds, and bank loans will encourage PPP investment after controlling the known determinants of PPP investments, and extends existing studies that focus on whether economic and institutional developments are critical determinants to attract private investment in infrastructure projects.

Figure 1 shows that PPP investment and the number of PPP projects have increased since 2003, and they reached the peak in 2012. Recently, both PPP investment and the number of PPP projects have decreased substantially since more stringent capital requirement regulation makes banks more reluctant to extend long-term and risky loans to infrastructure projects since the global financial crisis. Figure 2 shows that annual average PPP investment has been increasingly popular, especially in Brazil and India with relatively large investment among the 12 selected countries which are facing shortfalls in infrastructure financing.

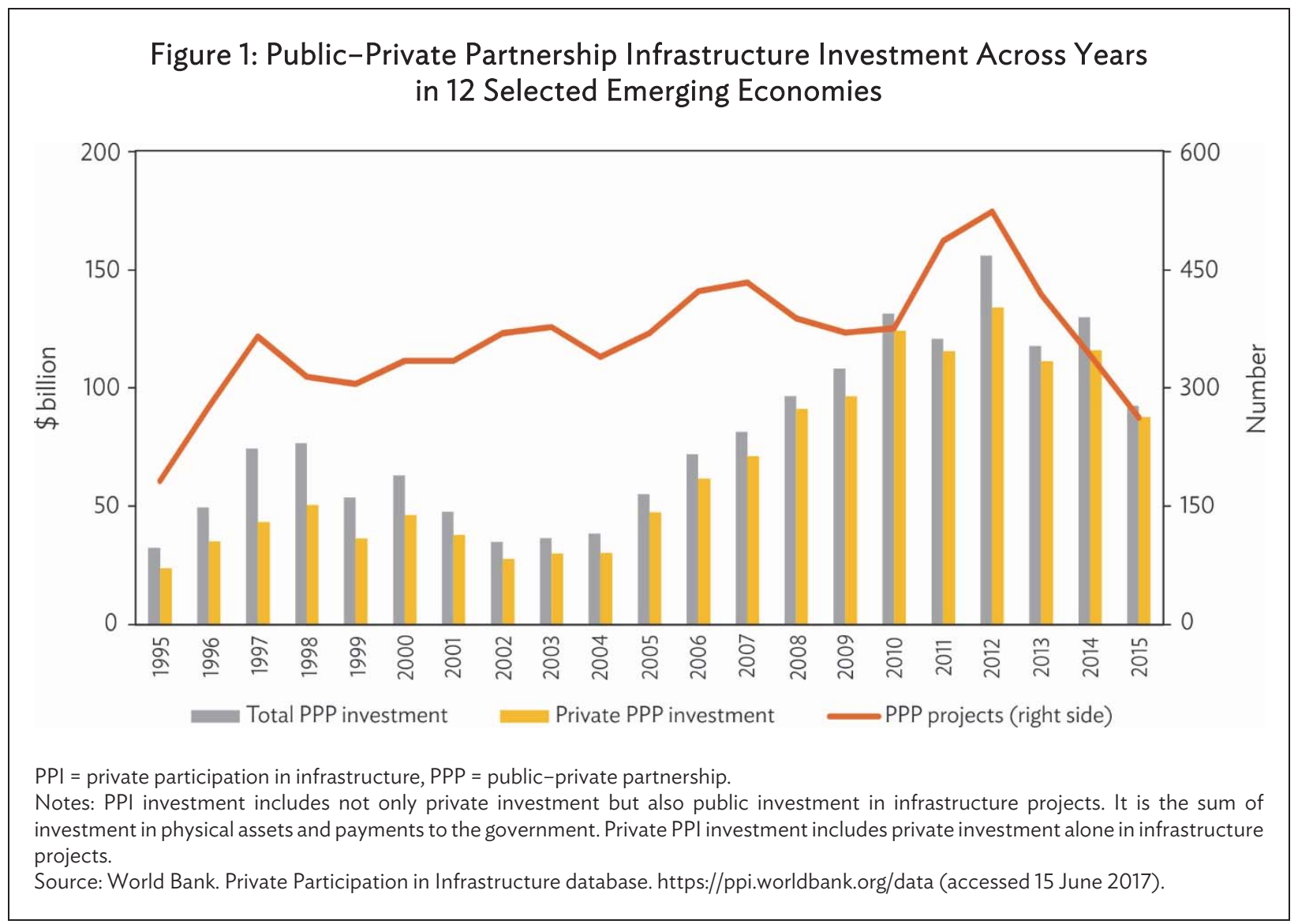


Figure 2: Annual Average of Public-Private Partnership Investment Across Countries

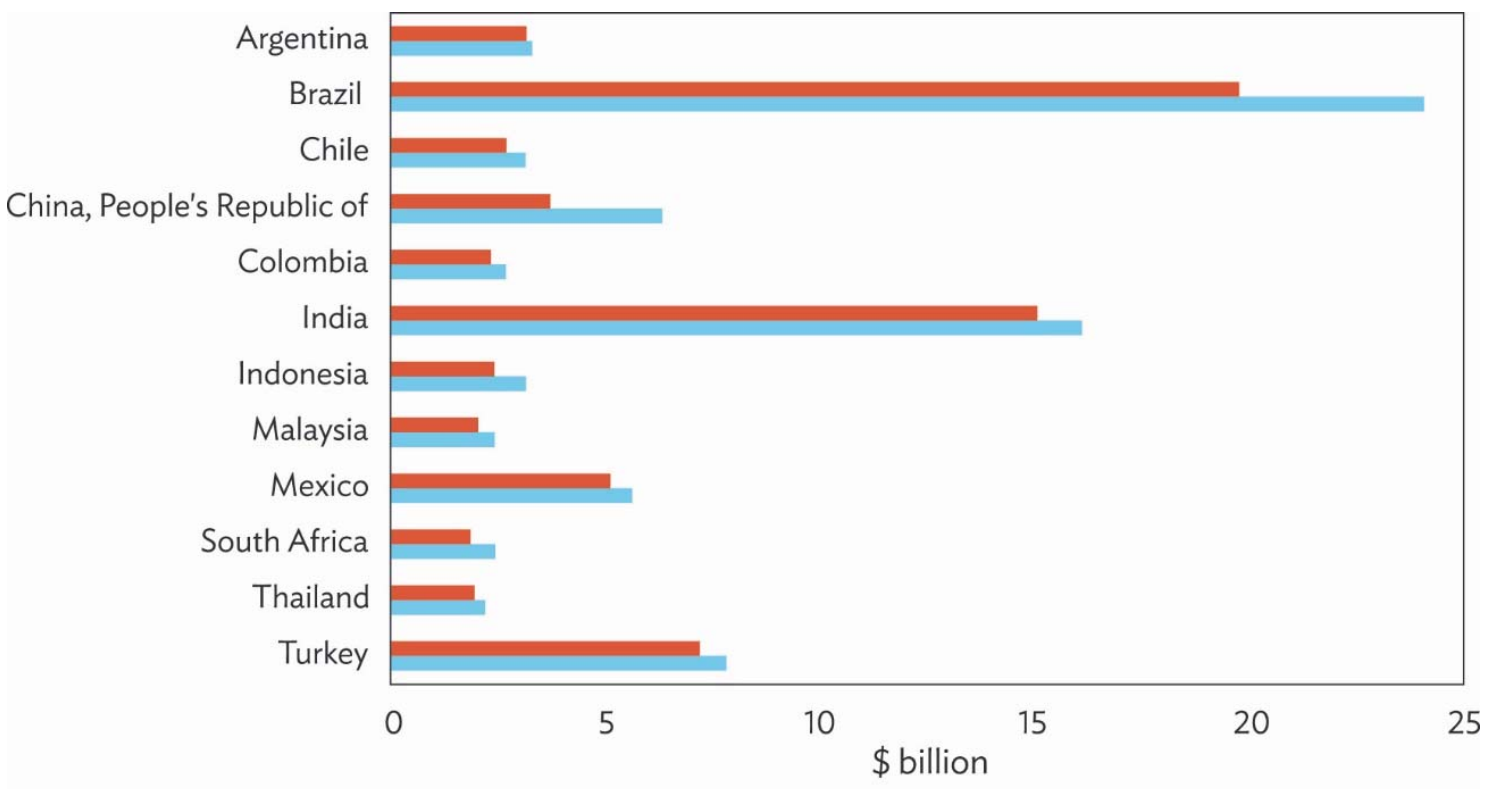

Annual average private PPP investment

Annual average PPP investment

$\mathrm{PPI}=$ private participation in infrastructure, $\mathrm{PPP}=$ public-private partnership.

Notes: PPI investment includes not only private investment but also public investment in infrastructure projects. It is the average of investment in physical assets and payments to the government in a given year. Private PPI investment includes private investment alone in infrastructure projects.

Source: World Bank. Private Participation in Infrastructure database. https://ppi.worldbank.org/data (accessed 15 June 2017).

\section{B. Empirical Analysis}

While the need for developing countries to foster private investment in their infrastructure sectors has been emphasized in the literature, there are very few papers to investigate the determinants of PPP investment in terms of financial and capital market development, as well as economic development. Therefore, this paper attempts to test whether the level of economic and finance sector development is a critical driver of private investment in developing countries' infrastructure projects, while controlling for other features of a country's economy.

To evaluate whether economic and finance sector development is a key determinant of aggregated PPP project investments and private participation in PPP investments in developing countries, we estimate a set of model specifications with the level of total investment and private investment in PPP projects as dependent variables, respectively. In addition to the independent variables of main interest, proxy variables standing for the levels of economic and finance sector development, government stability variable from International County Risk Guide dataset are included.

In addition to the major variables of interest, the first lagged dependent variable is also included as an independent variable to capture potential dynamics because PPP arrangements are more likely in 
countries with previous PPP experience. After all, PPPs are complex arrangements between two parties. Previous PPP experience reassures private investors about the quality of their PPP counterparts. Arellano and Bover (1995) and Blundell and Bond (1998) show that the system generalized method of moments (GMM) approach allows lagged first differences to be used as instruments for dynamic panel models in order to correct for any bias that might result from the standard GMM estimator. Especially the system GMM estimator proposed by Blundell and Bond (1998) has become a common tool in applied economic research using panel data because GMM provides asymptotically efficient inference assuming a minimal set of statistical assumptions. Blundell and Bond (1998) show that the standard GMM estimator has been found to have poor finite sample properties in the case in which the series are highly persistent. In this circumstance, the lagged levels of the series are only weakly correlated with subsequent first differences, consequently leading to weak instruments for the first-differenced equations.

To this end, we specify various econometric models from a benchmark panel regression to GMM developed by Arellano and Bond (1991) and Blundell and Bond (1998) for dynamic panel models.7 All regressions include time dummies intended to capture time-specific global shocks or systemic risks, and country dummies that capture potential country-specific characteristics. Tables 4-7 report panel regressions using panel fixed effect, difference GMM, and system GMM models.

First, interesting and unexpected finding is the negative and significant impact of bond market development on PPP investment. To further scrutinize this negative influence, we break down bond market into government bond market and corporate bond market, and we find that the negative impact is largely driven by the dominant government bonds, indicating that dominant government bond financing disincentivizes private investment because of limited financing accessibility due to a relatively small corporate bond market. Low- and middle-income developing countries still depend heavily on the fiscal financing for infrastructure projects instead of utilizing private investment. This might result from the underdeveloped corporate bond market in developing countries, which cannot provide enough longterm financing to the private sector for infrastructure investments.

PPP projects depend on market access to private borrowing, requiring the private sector to source the initial capital for projects upfront. PPP funds are ultimately sourced from the capital markets. This means that access to finance plays an essential role in determining the financial viability of PPP projects. In most PPP contracts, debt is limited recourse or nonrecourse, where financiers bear the risks. In practice, most stakeholders are not willing to accept excessive risks. The level of financial market development is a key determinant of the ease in which a PPP project can be facilitated. An underdeveloped financial market is often an obstacle to successful PPP projects, and the lack of financial market developments by host countries can also be another problem (Grimsey and Lewis 2004, Zhang 2001).

While private investors may provide a part or all of the funding, identifiable revenue stream sufficient to this investment should be provided. The income stream can be generated by a variety and combination of sources such as fees, tolls, availability payments, shadow tolls, and tax increment

7 Applying the Arellano and Bover (1995) and Blundell and Bond (1998) one-step system GMM approach for dynamic panel models to the data augmented through multiple imputation by chained equations, an increasingly popular approach for handling missing observations. 
financing. ${ }^{8}$ Also, project finance is a key success factor for private sector involvement in infrastructure projects. The availability of well-functioning financial market provides the benefits of low financing costs and diversified range of financial products, which consequently facilitate the private sector investment in PPP projects.

Second, the income level measured as GDP per capita is surprisingly negatively associated with PPP investment. The viability of an infrastructure project is basically secured by future cash flows and financing cost. Larger market size and consumer's purchasing power are good perspectives for potential cash flows. However, it is conjectured that, especially, countries with large populations cannot provide sufficient infrastructure access and service to their people because GDP growth is positively related to PPP investment, although it is not statistically significant. In the case of dynamic panel with fixed-effect regression, economic growth is also positively related to PPP investment, which indicates that countries with rapid growth and high demand for infrastructure tend to have more PPPs.

Third, macroeconomic variables have a direct effect on PPP projects. For example, the exchange rate can critically affect the viability of the PPP project since most projects are financed with mainly foreign capital in the form of loans and equities. Therefore, exchange risk is one of the important risks that limit investments in PPPs. Stable macroeconomic conditions encourage private investment. Therefore, higher inflation discourages PPP investment, as generally expected. Infrastructure projects such as highways, airports, and bridges have a long life span. Therefore, high inflation is a detrimental factor to investors who cannot hedge inflation for a long period of infrastructure. Macroeconomic stability is more common in countries with low inflation. Therefore, stable inflation is essential for PPP developments.

The results of GMM regressions show that pegged exchange rate regimes contribute positively to PPP investment although they are not statistically significant because such regimes can prevent the exchange rate from fluctuating. When infrastructure projects are financed with foreign capital, foreign investors can limit their foreign exchange risk exposure. However, revenue income generated from infrastructure projects is denominated in local currency; borrowers face currency mismatch problems.

Fourth, previous year volume of PPP investment is positively associated with current level of PPP investment, coefficients which are significant at the 1\% level in the dynamic model of Tables 6 and 7. The efficiency is reflected in public entities with previous experience in PPP projects, and with the capability to optimally allocate the risk between the public and the private sectors. Since PPPs are complex arrangements between two different parties, it is necessary for the public party to have the required expertise to successfully develop the PPP projects. The public entity's experience in PPP projects attracts more private investors who care about their counterpart in PPP contracts.

Fifth, in case of bank credit, empirical results seem unclear because more stringent capital requirement regulation has made banks reluctant to lend to PPP projects since the global financial crisis. Nevertheless, some results confirm that banks remain major fund suppliers to private infrastructure projects investments in GMM and dynamic panel regression. According to the World Economic Forum (2014), commercial banks provided an estimated $90 \%$ of all private debt for infrastructure financing

8 Tax increment financing is a public financing tool which is used to subsidize redevelopment, infrastructure, and other community-improvement projects by earmarking property tax revenue increments from assessed values within a designated tax increment financing district. 
from 1999 to 2009. Low-income developing economies are characterized by underdeveloped capital markets that could not offer long-term local currency financing. Moreover, these markets often involve only a limited number of players such as government banks or state-owned companies and, therefore, reduce pricing efficiency, distort yields, and ultimately lead to high transaction costs as Platz (2009) pointed out.

Table 4: Determinants of Public-Private Partnership: Panel Regression with Fixed Effect

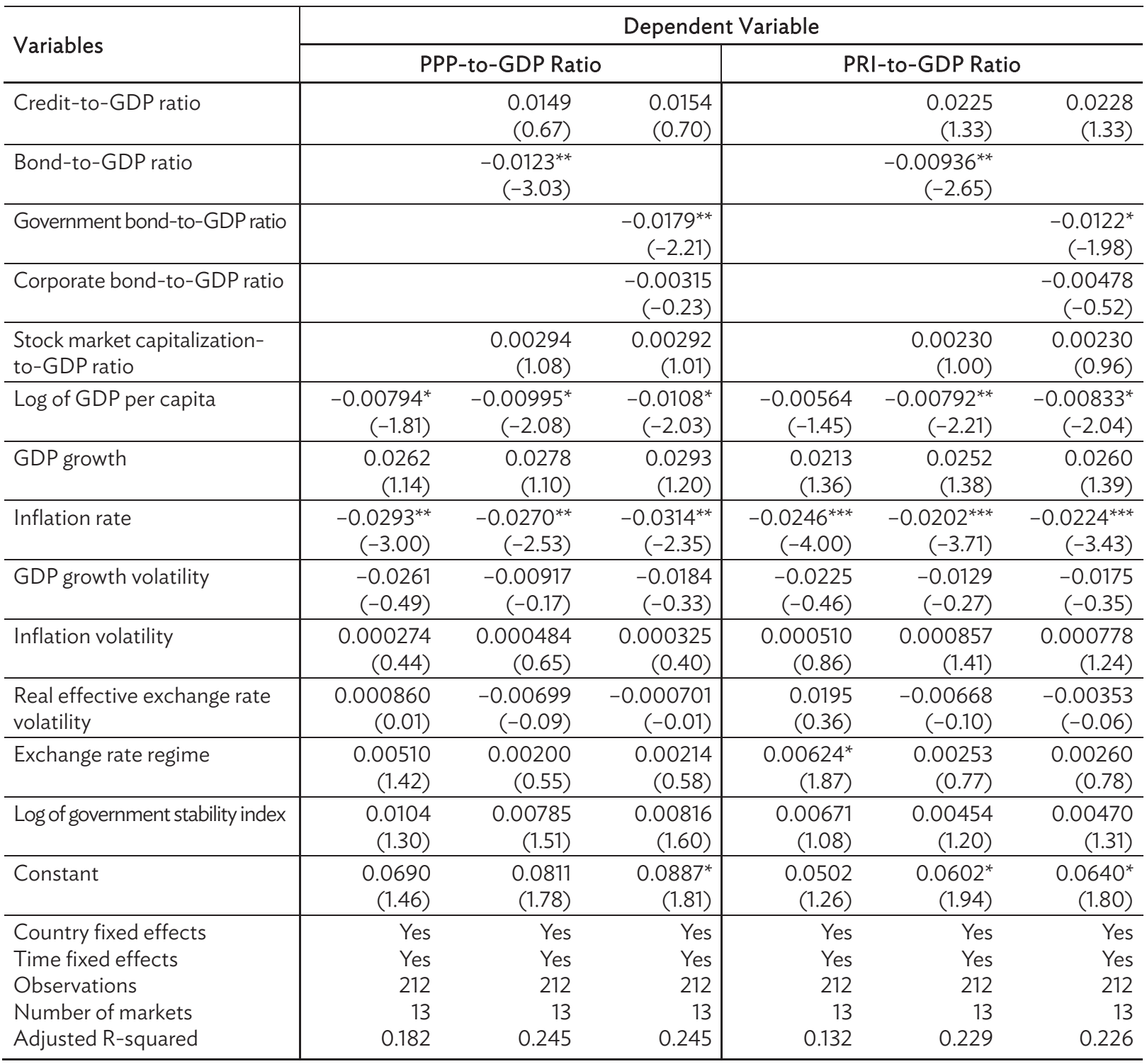

GDP = gross domestic product, $\mathrm{PPP}=$ public-private partnership, $\mathrm{PRI}=$ PPP private investment.

Notes: ${ }^{* *},{ }^{* *},{ }^{*}$ denote significance at $1 \%, 5 \%$ and $10 \%$ levels, respectively. $t$-values calculated from standard errors clustered at the country level in parenthesis. Time and country fixed effects are controlled.

Source: Authors' estimates. 


\section{Table 5: Determinants of Public-Private Partnership: Difference Generalized Method of Moments Regression}

\begin{tabular}{|c|c|c|c|c|c|c|}
\hline \multirow{3}{*}{$\begin{array}{l}\text { Variables } \\
\text { Credit-to-GDP ratio }\end{array}$} & \multicolumn{6}{|c|}{ Dependent Variable } \\
\hline & \multicolumn{3}{|c|}{ PPP-to-GDP Ratio } & \multicolumn{3}{|c|}{ PRI-to-GDP Ratio } \\
\hline & & $\begin{array}{r}0.00952 \\
(0.95) \\
\end{array}$ & $\begin{array}{r}0.00987 \\
(0.97) \\
\end{array}$ & & $\begin{array}{r}0.0184^{* *} \\
(2.20)\end{array}$ & $\begin{array}{r}0.0189^{* *} \\
(2.25)\end{array}$ \\
\hline Bond-to-GDP ratio & & $\begin{array}{r}-0.0110^{* * *} \\
(-2.75) \\
\end{array}$ & & & $\begin{array}{r}-0.00887^{* * *} \\
(-2.63)\end{array}$ & \\
\hline Government bond-to-GDP ratio & & & $\begin{array}{r}-0.0137^{*} \\
(-1.95) \\
\end{array}$ & & & $\begin{array}{r}-0.0115^{* *} \\
(-1.98) \\
\end{array}$ \\
\hline Corporate bond-to-GDP ratio & & & $\begin{array}{r}-0.00672 \\
(-0.66) \\
\end{array}$ & & & $\begin{array}{r}-0.00459 \\
(-0.54) \\
\end{array}$ \\
\hline $\begin{array}{l}\text { Stock market capitalization- } \\
\text { to-GDP ratio }\end{array}$ & & $\begin{array}{r}4.02 e-05 \\
(0.01) \\
\end{array}$ & $\begin{array}{r}0.000128 \\
(0.04) \\
\end{array}$ & & $\begin{array}{r}0.000901 \\
(0.36) \\
\end{array}$ & $\begin{array}{r}0.000903 \\
(0.36) \\
\end{array}$ \\
\hline Log of GDP per capita & $\begin{array}{r}-0.00658^{*} \\
(-1.73)\end{array}$ & $\begin{array}{r}-0.00828^{* *} \\
(-2.15)\end{array}$ & $\begin{array}{r}-0.00867^{* *} \\
(-2.19)\end{array}$ & $\begin{array}{r}-0.00451 \\
(-1.41) \\
\end{array}$ & $\begin{array}{r}-0.00701^{* *} \\
(-2.17)\end{array}$ & $\begin{array}{r}-0.00740^{* *} \\
(-2.24)\end{array}$ \\
\hline GDP growth & $\begin{array}{r}0.0219 \\
(0.82) \\
\end{array}$ & $\begin{array}{r}0.0251 \\
(0.93) \\
\end{array}$ & $\begin{array}{r}0.0260 \\
(0.96) \\
\end{array}$ & $\begin{array}{r}0.0157 \\
(0.71) \\
\end{array}$ & $\begin{array}{r}0.0239 \\
(1.08) \\
\end{array}$ & $\begin{array}{r}0.0249 \\
(1.11) \\
\end{array}$ \\
\hline Inflation rate & $\begin{array}{r}-0.0289^{* * *} \\
(-3.51)\end{array}$ & $\begin{array}{r}-0.0280^{* * *} \\
(-3.11)\end{array}$ & $\begin{array}{r}-0.0299^{* * *} \\
(-3.01) \\
\end{array}$ & $\begin{array}{r}-0.0249^{* * *} \\
(-3.73)\end{array}$ & $\begin{array}{r}-0.0217^{* * *} \\
(-2.97) \\
\end{array}$ & $\begin{array}{r}-0.0235^{* * *} \\
(-2.94) \\
\end{array}$ \\
\hline GDP growth volatility & $\begin{array}{r}0.0220 \\
(0.33) \\
\end{array}$ & $\begin{array}{r}0.0264 \\
(0.39) \\
\end{array}$ & $\begin{array}{r}0.0227 \\
(0.33) \\
\end{array}$ & $\begin{array}{r}0.0210 \\
(0.37) \\
\end{array}$ & $\begin{array}{r}0.00422 \\
(0.07) \\
\end{array}$ & $\begin{array}{r}0.000155 \\
(0.00) \\
\end{array}$ \\
\hline Inflation volatility & $\begin{array}{r}-0.000306 \\
(-0.49) \\
\end{array}$ & $\begin{array}{r}-0.000141 \\
(-0.22) \\
\end{array}$ & $\begin{array}{r}-0.000189 \\
(-0.29) \\
\end{array}$ & $\begin{array}{r}0.000337 \\
(0.64) \\
\end{array}$ & $\begin{array}{r}0.000546 \\
(1.00) \\
\end{array}$ & $\begin{array}{r}0.000494 \\
(0.89) \\
\end{array}$ \\
\hline $\begin{array}{l}\text { Real effective exchange rate } \\
\text { volatility }\end{array}$ & $\begin{array}{r}-0.0133 \\
(-0.26) \\
\end{array}$ & $\begin{array}{r}0.00149 \\
(0.03) \\
\end{array}$ & $\begin{array}{r}0.00522 \\
(0.09) \\
\end{array}$ & $\begin{array}{r}0.00517 \\
(0.12) \\
\end{array}$ & $\begin{array}{r}-0.00228 \\
(-0.05) \\
\end{array}$ & $\begin{array}{r}0.00112 \\
(0.02) \\
\end{array}$ \\
\hline Exchange rate regime & $\begin{array}{r}0.00502^{*} \\
(1.86) \\
\end{array}$ & $\begin{array}{r}0.00251 \\
(0.87) \\
\end{array}$ & $\begin{array}{r}0.00259 \\
(0.89) \\
\end{array}$ & $\begin{array}{r}0.00683^{* * *} \\
(3.06)\end{array}$ & $\begin{array}{r}0.00311 \\
(1.30) \\
\end{array}$ & $\begin{array}{r}0.00317 \\
(1.31) \\
\end{array}$ \\
\hline Log of government stability index & $\begin{array}{r}0.00584 \\
(1.15) \\
\end{array}$ & $\begin{array}{r}0.00554 \\
(1.09) \\
\end{array}$ & $\begin{array}{r}0.00577 \\
(1.13) \\
\end{array}$ & $\begin{array}{r}0.00306 \\
(0.73) \\
\end{array}$ & $\begin{array}{r}0.00333 \\
(0.79) \\
\end{array}$ & $\begin{array}{r}0.00354 \\
(0.83) \\
\end{array}$ \\
\hline Country fixed effects & Yes & Yes & Yes & Yes & Yes & Yes \\
\hline Time fixed effects & Yes & Yes & Yes & Yes & Yes & Yes \\
\hline Observations & 199 & 199 & 199 & 199 & 199 & 199 \\
\hline Number of markets & 13 & 13 & 13 & 13 & 13 & 13 \\
\hline F Value & 4.075 & 4.143 & 3.984 & 3.243 & 3.544 & 3.428 \\
\hline
\end{tabular}

$\mathrm{GDP}=$ gross domestic product, $\mathrm{PPP}=$ public-private partnership, $\mathrm{PRI}=\mathrm{PPP}$ private investment.

Notes: ${ }^{* *},{ }^{* *},{ }^{*}$ denote significance at $1 \%, 5 \%$ and $10 \%$ levels, respectively. $\mathrm{t}$-values calculated from standard errors clustered at the country level in parenthesis. Time and country fixed effects are controlled.

Source: Authors. 
Table 6: Determinants of Public-Private Partnership: Dynamic Panel Fixed Effect Regression

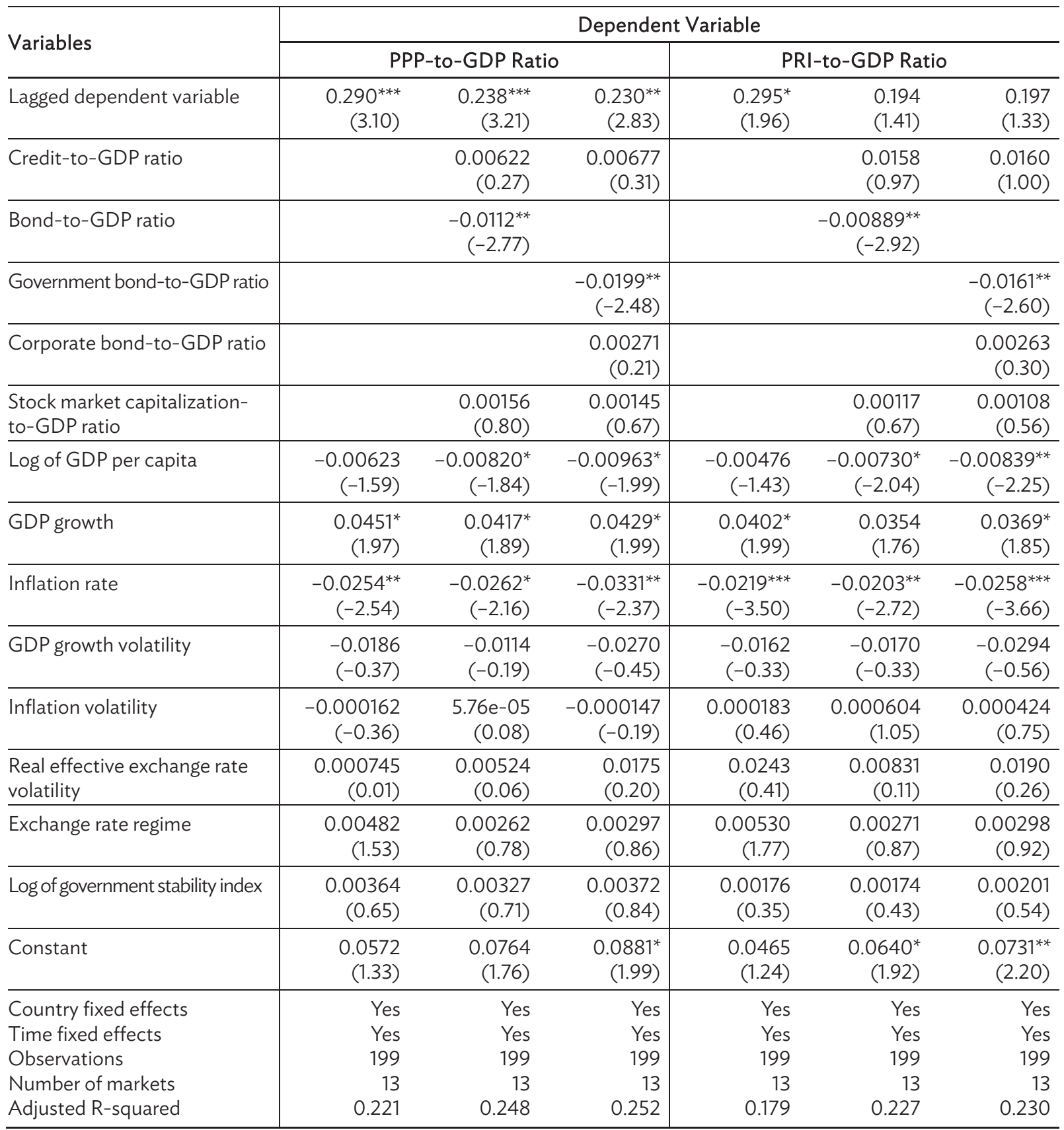

GDP = gross domestic product, $\mathrm{PPP}=$ public-private partnership, $\mathrm{PRI}=$ PPP private investment.

Notes: ${ }^{* * *},{ }^{* *},{ }^{*}$ denote significance at $1 \%, 5 \%$ and $10 \%$ levels, respectively. $t$-values calculated from standard errors clustered at the country level in parenthesis. Time and country fixed effects are controlled.

Source: Authors' estimates. 


\section{Table 7: Determinants of Public-Private Partnership: System Generalized Method of Moments Regression}

\begin{tabular}{|c|c|c|c|c|c|c|}
\hline \multirow{3}{*}{$\begin{array}{l}\text { Variables } \\
\text { Lagged dependent variable }\end{array}$} & \multicolumn{6}{|c|}{ Dependent Variable } \\
\hline & \multicolumn{3}{|c|}{ PPP-to-GDP Ratio } & \multicolumn{3}{|c|}{ PRI-to-GDP Ratio } \\
\hline & $\begin{array}{c}0.343^{* * *} \\
(4.48)\end{array}$ & $\begin{array}{c}0.242^{* * *} \\
(3.13)\end{array}$ & $\begin{array}{r}0.247^{* * *} \\
(3.19)\end{array}$ & $\begin{array}{c}0.314^{* * *} \\
(3.87)\end{array}$ & $\begin{array}{l}0.187^{* *} \\
(2.28)\end{array}$ & $\begin{array}{r}0.190^{* *} \\
(2.31)\end{array}$ \\
\hline Credit-to-GDP ratio & & $\begin{array}{r}0.0215^{* *} \\
(2.45)\end{array}$ & $\begin{array}{r}0.0224^{* *} \\
(2.49)\end{array}$ & & $\begin{array}{r}0.0224^{* * *} \\
(3.14)\end{array}$ & $\begin{array}{r}0.0239^{* * *} \\
(3.28)\end{array}$ \\
\hline Bond-to-GDP ratio & & $\begin{array}{r}-0.0105^{* * *} \\
(-2.65)\end{array}$ & & & $\begin{array}{r}-0.00826^{* *} \\
(-2.57)\end{array}$ & \\
\hline Government bond-to-GDP ratio & & & $\begin{array}{r}-0.0158^{* *} \\
(-2.14)\end{array}$ & & & $\begin{array}{r}-0.0144^{* *} \\
(-2.38)\end{array}$ \\
\hline Corporate bond-to-GDP ratio & & & $\begin{array}{r}-0.00211 \\
(-0.20) \\
\end{array}$ & & & $\begin{array}{r}0.00125 \\
(0.15) \\
\end{array}$ \\
\hline $\begin{array}{l}\text { Stock market capitalization- } \\
\text { to-GDP ratio }\end{array}$ & & $\begin{array}{r}-0.000185 \\
(-0.07) \\
\end{array}$ & $\begin{array}{r}7.59 e-05 \\
(0.03) \\
\end{array}$ & & $\begin{array}{r}0.000235 \\
(0.11) \\
\end{array}$ & $\begin{array}{r}0.000155 \\
(0.07) \\
\end{array}$ \\
\hline Log of GDP per capita & $\begin{array}{r}-0.00293 \\
(-1.19) \\
\end{array}$ & $\begin{array}{r}-0.00518^{*} \\
(-1.90)\end{array}$ & $\begin{array}{r}-0.00593^{*} \\
(-1.97) \\
\end{array}$ & $\begin{array}{r}-0.00148 \\
(-0.74) \\
\end{array}$ & $\begin{array}{r}-0.00380^{*} \\
(-1.75)\end{array}$ & $\begin{array}{r}-0.00500^{* *} \\
(-2.08) \\
\end{array}$ \\
\hline GDP growth & $\begin{array}{r}0.0101 \\
(0.41)\end{array}$ & $\begin{array}{l}0.0161 \\
(0.68)\end{array}$ & $\begin{array}{l}0.0175 \\
(0.73)\end{array}$ & $\begin{array}{l}0.0170 \\
(0.85)\end{array}$ & $\begin{array}{r}0.0226 \\
(1.18)\end{array}$ & $\begin{array}{r}0.0249 \\
(1.29)\end{array}$ \\
\hline Inflation rate & $\begin{array}{r}-0.0121 \\
(-1.41)\end{array}$ & $\begin{array}{r}-0.0139 * \\
(-1.78) \\
\end{array}$ & $\begin{array}{r}-0.0182^{* *} \\
(-2.16) \\
\end{array}$ & $\begin{array}{r}-0.0142^{* *} \\
(-2.02) \\
\end{array}$ & $\begin{array}{r}-0.0151^{* *} \\
(-2.40) \\
\end{array}$ & $\begin{array}{r}-0.0188^{* * *} \\
(-2.69) \\
\end{array}$ \\
\hline GDP growth volatility & $\begin{array}{r}-0.0278 \\
(-0.36)\end{array}$ & $\begin{array}{r}-0.0312 \\
(-0.43)\end{array}$ & $\begin{array}{r}-0.0399 \\
(-0.54)\end{array}$ & $\begin{array}{l}-0.0221 \\
(-0.35)\end{array}$ & $\begin{array}{r}-0.0218 \\
(-0.37)\end{array}$ & $\begin{array}{r}-0.0354 \\
(-0.59)\end{array}$ \\
\hline Inflation volatility & $\begin{array}{r}0.000503 \\
(0.72) \\
\end{array}$ & $\begin{array}{r}0.000437 \\
(0.66) \\
\end{array}$ & $\begin{array}{r}0.000460 \\
(0.69) \\
\end{array}$ & $\begin{array}{r}0.000554 \\
(0.96)\end{array}$ & $\begin{array}{r}0.000567 \\
(1.06) \\
\end{array}$ & $\begin{array}{r}0.000521 \\
(0.96) \\
\end{array}$ \\
\hline $\begin{array}{l}\text { Real effective exchange rate } \\
\text { volatility }\end{array}$ & $\begin{array}{r}-0.0309 \\
(-0.53) \\
\end{array}$ & $\begin{array}{r}-0.0420 \\
(-0.73) \\
\end{array}$ & $\begin{array}{r}-0.0345 \\
(-0.60) \\
\end{array}$ & $\begin{array}{r}0.00380 \\
(0.08) \\
\end{array}$ & $\begin{array}{r}-0.00599 \\
(-0.13) \\
\end{array}$ & $\begin{array}{r}-0.00286 \\
(-0.06) \\
\end{array}$ \\
\hline Exchange rate regime & $\begin{array}{r}0.00568^{*} \\
(1.88) \\
\end{array}$ & $\begin{array}{r}0.00141 \\
(0.46) \\
\end{array}$ & $\begin{array}{r}0.00144 \\
(0.47) \\
\end{array}$ & $\begin{array}{r}0.00617^{* *} \\
(2.46)\end{array}$ & $\begin{array}{r}0.00233 \\
(0.94) \\
\end{array}$ & $\begin{array}{r}0.00237 \\
(0.95) \\
\end{array}$ \\
\hline Log of government stability index & $\begin{array}{r}0.00376 \\
(0.77)\end{array}$ & $\begin{array}{r}0.00300 \\
(0.63)\end{array}$ & $\begin{array}{r}0.00380 \\
(0.80)\end{array}$ & $\begin{array}{r}0.000902 \\
(0.23)\end{array}$ & $\begin{array}{r}0.000497 \\
(0.13)\end{array}$ & $\begin{array}{r}0.000813 \\
(0.21)\end{array}$ \\
\hline Country fixed effects & Yes & Yes & Yes & Yes & Yes & Yes \\
\hline Time fixed effects & Yes & Yes & Yes & Yes & Yes & Yes \\
\hline Observations & 186 & 186 & 186 & 186 & 186 & 186 \\
\hline Number of markets & 13 & 13 & 13 & 13 & 13 & 13 \\
\hline Fvalue & 6.010 & 6.448 & 6.078 & 5.467 & 6.358 & 5.907 \\
\hline
\end{tabular}

$\mathrm{GDP}=$ gross domestic product, $\mathrm{PPP}=$ public-private partnership, $\mathrm{PRI}=\mathrm{PPP}$ private investment.

Notes: ${ }^{* * *},{ }^{* *},{ }^{*}$ denote significance at $1 \%, 5 \%$ and $10 \%$ levels, respectively. t-values calculated from standard errors clustered at the country level in parenthesis. Time and country fixed effects are controlled.

Source: Authors. 


\section{CONCLUSION}

PPPs are at the core of governments' efforts to attract infrastructure investments in developing economies. However, private investments cannot be made without mitigating considerable risks inherent in infrastructure projects. The government might fail to provide private sector sponsors or operators with sufficient incentives to design and monitor their projects carefully, if the government shows its explicit or implicit readiness to cover the loss of failed projects in any event. In general, commercial risks are best controlled and absorbed by the private parties involved in the project, while political and regulatory risks are in the hands of the government.

Neither governments nor private firms alone are likely to have the resources enough to build essential infrastructure and to cover all the risks inherent in infrastructure projects. Therefore, an optimal risk- and profit-sharing mechanism must be designed to strike a balance between the project's public nature and viability that is an incentive for private financing. Hyun, Nishizawa, and Yoshino (2008) insist that it is very critical to design a risk-sharing mechanism to prevent moral hazard and to strike a balance between the public nature of a project and its commercial viability that is an incentive for private sectors. ${ }^{9}$

Determinants of PPPs presented in this paper go a long way toward identifying further factors that stimulate PPPs. Our results indicate that macroeconomic factors such as economic growth and inflation are the most relevant determinants of PPP investments. From the perspective of macroeconomic stability, inflation, and exchange rate instability could limit private PPP investment. And our results show the significance of previous PPP experience in facilitating additional PPPs.

Our new findings indicate that bond market development is not a critical determinant of PPPs. Moreover, PPP investment, especially private PPP investment, would be crowded out when bond market is still underdeveloped to finance the infrastructure projects and dominated with government bonds. Although the negative impact of bond market development and income level on PPP investment should be further investigated, it can be interpreted that countries with larger population and, therefore, have greater demand for infrastructure tend to face insufficient PPP investments.

Most emerging countries still are heavily dependent upon fiscal financing for infrastructure projects because of underdeveloped corporate bond markets and banks being the major financing sources for private sectors. ${ }^{10}$ Empirical results also confirm the fact that banks remain major financiers of infrastructure projects. Banks with short-term liabilities are not well suited to hold long-term assets like PPP projects on their balances sheets from the perspective of asset liability management. Since the onset of the financial crisis, commercial bank debt under Basel III has become more difficult to secure and lending terms have worsened, affecting the bankability and value for money of PPP projects.

The current financial market conditions have rendered bond financing to play a pivotal role in closing the financing gap for infrastructure investments. Moreover, revenues from infrastructure projects are usually generated in local currency, while major financing sources are foreign banks that lend in

9 For details, refer to Hyun, Nishizawa, and Yoshino. 2008. Exploring the Use of Revenue Bond for Infrastructure Financing in Asia. JBICI DISCUSSION PAPER No. 15.

10 Regions and countries where market conditions are largely in place already for an infrastructure project bond markets are Canada; Australia; the United States; Mexico; Latin America, notably Brazil; the United Kingdom; France; Benelux (Belgium, the Netherlands, Luxembourg); and Germany according to PriceWaterhouseCoopers (2013). 
foreign currency. This poses a "double-mismatch problem" in terms of maturity and currency as was experienced during the 1997/1998 Asian financial crisis. On top of the double-mismatch problem, the decreasing capacity for commercial banks to finance long-term infrastructure projects also limits financial access to infrastructure investments.

Because of this, domestic bond markets should be developed to increase their depth and liquidity at the level that can provide long-term funding to private sector investors. Regional development banks such as the Asian Development Bank have an important role to play in assisting Asia's developing economies in this effort in line with regional initiatives, such as the Asian Bond Markets Initiative (ABMI)."

1 ABMI was launched in 2003 collectively by ASEAN+3 to strengthen the resilience of the region's financial system by developing local currency bond markets as an alternative source to foreign currency-denominated, short-term bank loans for long-term investment financing. 


\section{APPENDIX: VARIABLE DEFINITION}

\begin{tabular}{|c|c|c|}
\hline Variable Name & Variable Definition & Data Source \\
\hline PPP-to-GDP ratio & Aggregated PPP total investment of PPP projects ( $\$$ million) & $\begin{array}{l}\text { World Bank, Private } \\
\text { Participation in } \\
\text { Infrastructure Database }\end{array}$ \\
\hline PRI-to-GDP ratio & Aggregated private investment in PPP projects ( $\$$ million) & $\begin{array}{l}\text { World Bank, Private } \\
\text { Participation in } \\
\text { Infrastructure Database }\end{array}$ \\
\hline Credit-to-GDP ratio & $\begin{array}{l}\text { Total credit extended by domestic banks to private } \\
\text { nonfinancial sector as a percentage of GDP }\end{array}$ & $\begin{array}{l}\text { Bank for International } \\
\text { Settlements }\end{array}$ \\
\hline Bond-to-GDP ratio & $\begin{array}{l}\text { Total debt securities outstanding in both international and } \\
\text { domestic markets as a percentage of GDP }\end{array}$ & $\begin{array}{l}\text { Bank for International } \\
\text { Settlements }\end{array}$ \\
\hline $\begin{array}{l}\text { Government bond-to- } \\
\text { GDP ratio }\end{array}$ & $\begin{array}{l}\text { Outstanding debt securities issued by governments as a } \\
\text { percentage of GDP }\end{array}$ & $\begin{array}{l}\text { Bank for International } \\
\text { Settlements }\end{array}$ \\
\hline $\begin{array}{l}\text { Corporate bond-to- } \\
\text { GDP ratio }\end{array}$ & $\begin{array}{l}\text { Outstanding debt securities issued by nongovernment entities } \\
\text { (difference between total outstanding debt securities and } \\
\text { government debt securities) as a percentage of GDP }\end{array}$ & $\begin{array}{l}\text { Bank for International } \\
\text { Settlements }\end{array}$ \\
\hline $\begin{array}{l}\text { Stock market } \\
\text { capitalization-to- } \\
\text { GDP ratio }\end{array}$ & Stock market capitalization as a percentage of GDP & $\begin{array}{l}\text { World Bank, World } \\
\text { Development Indicators } \\
\text { Database }\end{array}$ \\
\hline Log of GDP per capita & Natural logarithm of GDP per capita ( $\$$ current) & $\begin{array}{l}\text { World Bank, World } \\
\text { Development Indicators } \\
\text { Database }\end{array}$ \\
\hline GDP growth & Annual GDP growth rate in percentage & $\begin{array}{l}\text { World Bank, World } \\
\text { Development Indicators } \\
\text { Database }\end{array}$ \\
\hline Inflation rate & Annual CPI growth rate in percentage & $\begin{array}{l}\text { World Bank, World } \\
\text { Development Indicators } \\
\text { Database }\end{array}$ \\
\hline GDP growth volatility & Standard deviation of rolling $10-$ year annual GDP growth rate & $\begin{array}{l}\text { World Bank, World } \\
\text { Development Indicators } \\
\text { Database }\end{array}$ \\
\hline Inflation volatility & Standard deviation of rolling 10-year annual CPI price change & $\begin{array}{l}\text { World Bank, World } \\
\text { Development Indicators } \\
\text { Database }\end{array}$ \\
\hline $\begin{array}{l}\text { Real effective exchange } \\
\text { rate volatility }\end{array}$ & $\begin{array}{l}\text { Standard deviation of monthly prices changes of real effective } \\
\text { exchange rate }\end{array}$ & $\begin{array}{l}\text { Calculated from Bank for } \\
\text { International Settlements } \\
\text { data }\end{array}$ \\
\hline Exchange rate regime & $\begin{array}{l}\text { Exchange rate regime according to standard Shambaugh } \\
(2004) \text { classification }(1=\text { peg, } 0=\text { nonpeg })\end{array}$ & Shambaugh (2004) \\
\hline $\begin{array}{l}\text { Log of government } \\
\text { stability index }\end{array}$ & Natural logarithm of ICRG government stability index & $\begin{array}{l}\text { The PRS Group, } \\
\text { International Country } \\
\text { Risk Guide dataset }\end{array}$ \\
\hline
\end{tabular}

$\mathrm{CPI}=$ consumer price index, GDP = gross domestic product, ICRG = International Country Risk Guide, PPP = public-private partnership, PRI = PPP private investment.

Source: Authors' compilation. 


\section{REFERENCES}

Arellano, Manuel, and Stephen Bond. 1991. "Some Tests of Specification for Panel Data: Monte Carlo Evidence and an Application to Employment Equations." The Review of Economic Studies 58 (2): 277-97.

Arellano, Manuel, and Olympia Bover. 1995. "Another Look at the Instrumental Variable Estimation of Error-Components Models." Journal of Econometrics 68 (1): 29-51.

Asante, Yaw. 2000. "Determinants of Private Investment Behaviour in Ghana." African Economic Research Consortium Research Paper 1000.

Ba, Lika, Farid Gasmi, and Paul Noumba Um. 2010. "Is the Level of Financial Sector Development a Key Determinant of Private Investment in the Power Sector?” World Bank Policy Research Working Paper WPS5373.

Blundell, Richard, and Stephen Bond. 1998. "Initial Conditions and Moment Restrictions in Dynamic Panel Data Models.” Journal of Econometrics 87 (1): 115-43.

Grimsey, Darrin, and Mervyn Lewis. 2002. "Evaluating the Risks for Public Private Partnerships for Infrastructure Projects.” International Journal of Project Management (20): 107-18.

2004. Public Private Partnerships: The Worldwide Revolution in Infrastructure Provision and Project Finance. United Kingdom: Edward Elgar.

Gupta, L. C., and C. P. Gupta. 2001. Financing Infrastructure Development: A Holistic Approach with Special Reference to the Power Sector. New Delhi: Society for Capital Market Research \& Development Report.

Hammami, Mona, J. Jean-Francois Ruhashyankiko, and Etienne Yehoue. 2006. "Determinants of Public-Private Partnerships in Infrastructure.” IMF Working Paper W/06/99.

Hoffman, Scott. 1998. The Law and Business of International Project Finance. London: Kluwer Law International.

Hyun, Suk, Toshiro Nishizawa, and Naoyuki Yoshino. 2008. "Exploring the Use of Revenue Bond for Infrastructure Financing in Asia.” JBICI Discussion Paper No. 15.

Jerome, Afeikhena. 2008. "Private Sector Participation in Infrastructure in Africa." Mimeo. African Peer Review Mechanism Secretariat. http://ssrn.com/abstract=1259219.

Kasri, Rahmatina Awaliah, and Farid Ariff Wibowo. 2015. "Determinants of Public-Private Partnerships in Infrastructure Provision: Evidence from Muslim Developing Countries.” Journal of Economic Cooperation and Development 36 (2): 1-34.

Kinda, Tidiane. 2008. "Infrastructure and Private Capital Flows in Developing Countries." Munich Personal RePEc Archive Paper 19158. 
Moszoro, Marian. 2014. "Efficient Public-Private Capital Structures." Annals of Public and Cooperative Economics, 103-26.

Moszoro, Marian, and Pawel Gąsiorowski. 2008. "Optimal Capital Structure of Public-Private Joint Ventures.” IMF Working Paper W/08/01.

Ouattara, Bazoumana. 2004. "Modelling the Long Run Determinants of Private Investment in Senegal." University of Nottingham Centre for Research in Economic Development and International Trade Research 04/05.

Platz, Daniel. 2009. "Infrastructure Finance in Developing Countries: The Potential of Sub-sovereign Bonds." United Nations Department of Economic and Social Affairs Working Paper 76.

PriceWaterhouseCoopers. 2013. Capital Markets: The Rise of Non-Bank Infrastructure Project Finance. United Kingdom.

Saidi, Nasser. 2006. "Infrastructure: Key to Economic and Financial Development in MENA." Mimeo. Dubai: International Financial Centre Authority.

Sawada, Yasuyuki. 2015. "The Impacts of Infrastructure in Development: A Selected Survey." ADBI Working Paper Series No. 511.

Shambaugh, Jay. 2004. "The Effect of Fixed Exchange Rates on Monetary Policy.” Quarterly Journal of Economics. 119 (1): 301-52.

Sharma, Chandan. 2012. "Determinants of PPP in Infrastructure in Developing Economies." Transforming Government: People, Process and Policy 6 (2): 149-66.

Sheppard, Robert, Stephan von Klaudy, and Geeta Kumar. 2006. "Financing Infrastructure in Africa." Gridlines Note No. 13. Public-Private Infrastructure Advisory Facility, World Bank

Singh, Laishram, and Satyanarayana Kalidindi. 2009. "Criteria Influencing Debt Financing of Indian PPP Road Projects: A Case Study.” Journal of Financial Management of Property and Construction 14 (1): 34-60.

Tewodaj, Mengistu. 2013. "Determinants of Private Participation in Infrastructure in Low and MiddleIncome Countries (LMICs)." Pardee RAND Graduate School.

Thomsen, Stephen. 2005. "Encouraging PPP in the Utilities Sector: The Role of Development Assistance.” NEPAD/OECD Investment Initiative, Investment for African Development: Making it Happen, Background Information in Support of Session 5 Roundtable, Uganda, 25-27 May.

World Bank. Private Participation in Infrastructure database. https://ppi.worldbank.org/data.

—. 2006. "Private Participation in Infrastructure: Lessons Learned." OECD Global Forum for International Investment, Istanbul, 6-7 November.

World Economic Forum. 2014. Infrastructure Investment Policy Blueprint." Geneva. 
Yescombe, Edward. 2002. Principles of Project Finance. San Diego, CA: Academic Press.

2007. Public-Private Partnerships-Principles of Policy and Finance. 1st ed. London, UK: Butterworth-Heinemann.

Zerfu, Daniel. 2001. “Determinants of Private Investment in Ethiopia.” Mimeo. Addis Ababa University.

Zhang, Xueqing. 2001. "Procurement of Privately Financed Infrastructure Projects." PhD thesis, The University of Hong Kong. 


\section{Determinants of Public-Private Partnerships in Infrastructure in Asia: Implications for Capital Market Development}

This paper investigates how financial accessibility to private sectors such as stocks, bonds, and bank loans encourage public-private partnership (PPP) investments in developing countries. It extends existing studies on known determinants of PPPs and analyzes data using the World Bank Private Participation in Infrastructure database. Results reveal further factors that stimulate PPPs and the most relevant determinants of PPP investments. Recommendations call for an optimal risk- and profit-sharing mechanism that can strike a balance between the public nature of infrastructure investments and viability for private financing. There is also a need to further develop bond markets to help provide long-term funding for infrastructure investments.

\section{About the Asian Development Bank}

ADB is committed to achieving a prosperous, inclusive, resilient, and sustainable Asia and the Pacific, while sustaining its efforts to eradicate extreme poverty. Established in 1966, it is owned by 67 members48 from the region. Its main instruments for helping its developing member countries are policy dialogue, loans, equity investments, guarantees, grants, and technical assistance. 